\title{
Acceptability level of developed Phulkari embroidered Kurtis by adaptation of traditional Phulkari motifs
}

\author{
NEELAM SAINI, KRISHNA KHAMBRA AND SAROJ YADAV
}

Received: 18.02.2017; Revised: 18.09.2017; Accepted: 04.10.2017

See end of the paper for authors' affiliations

NEELAM SAINI

Department of Textile and Apparel

Designing, I.C. College of Home Science,

C.C.S. Haryana Agricultural University, HISAR (HARYANA) INDIA

Email : sainineelam004@ gmail.com
ABSTRACT : The study was conducted in Hisar city of Haryana state. Motifs of Phulkari embroidery were collected from Hisar and Patiala markets and categorized according to their categories i.e. geometrical, floral and animal. These were collected from secondary sources. Out of forty five motifs only fifteen were selected to develop stylized designs for Kurtis, each were converted into two designs. Then total thirty designs were developed with the help of Coral Draw. Five top ranked designs were selected. Then top five ranked placements of each selected designs was worked in Phulkari embroidery for making Kurtis. Finally five kurtis were developed. The opinion of experts was sought the most favourable about the cost of developed kurtis.

KEY WORDS: Phulkari, Embroidery, Kurti, Traditional, Adaptation

-HOW TO CITE THIS PAPER : Saini, Neelam, Khambra, Krishna and Yadav, Saroj (2017). Acceptability level of developed Phulkari embroidered Kurtis by adaptation of traditional Phulkari motifs. Asian J. Home Sci., 12 (2) : 334-338, DOI: 10.15740/HAS/AJHS/12.2/334-338. 